Article

\title{
Do Capital Flows Matter for Monetary Policy Setting in Inflation Targeting Economies?
}

\author{
Trinil Arimurti and Bruce Morley * \\ Department of Economics, University of Bath, Bath B2A 7AY, UK; ta501@bath.ac.uk \\ * Correspondence: bm232@bath.ac.uk; Tel.: +44-1225-386497
}

Received: 10 June 2020; Accepted: 28 June 2020; Published: 30 June 2020

\begin{abstract}
The aim of this study is to determine if capital flows can account for the international effects on domestic monetary policy, using an augmented Taylor rule model. In addition to the standard determinants of nominal interest rates, we include capital flow measures to show how central banks consider this important factor when deciding on the most appropriate monetary policy. Using a panel of inflation targeting economies and the dynamic panel approach, this study finds that capital inflows and outflows are an important determinant of nominal interest rates.
\end{abstract}

Keywords: capital flow; Taylor rule; interest rate

\section{Introduction}

The aim of this study is to determine whether capital flows are an important factor in deciding the nominal interest rate in a sample of inflation targeting countries. Recently capital flows between countries have had an increasingly strong impact on the macroeconomies and financial markets across the world. A particular instance of this was the 'taper tantrum' following the decision by the Federal Reserve to reduce the use of alternative monetary policies, which caused a sudden outflow of capital from across the world back to the US. This caused a depreciation of the exchange rate in countries suffering the outflow and appreciation of the US dollar, with the consequent implications for these countries monetary policies.

Since being introduced by Taylor (1993), the Taylor rule has become a major factor for consideration by central banks when setting the interest rate reaction function. According to this rule, there is a simple linear relationship between the interest rate, inflation rate and the output gap. Originally, Taylor (1993) set a representative policy rule for the US economy based on the economic conditions at that time, by applying a certain weight to the price level and real output, even though there was no specific consensus established on the parameter size in the rule. This rule has now become a popular assessment approach for modelling the monetary policy stance of the central banks both in the advanced and emerging economies.

The standard version of the Taylor rule in Taylor (1993) was intended to be a general policy framework for central banks when assessing their interest rate decisions (Taylor 2001). In reality, depending on the economic conditions, the central bank might need to do some adjustments or discretions to this normative guideline. As an example, from the early 2000s until the outbreak of the global financial crisis, the short-term policy rates in some advanced economies deviated substantially, when it was set to below what the rule suggested it should be (Taylor 2007).

In recent years, the literature on the rule has taken into account a wider set of information that is relevant to the current economic conditions. This version is known as the augmented version of the Taylor rule. Some important indicators like exchange rates, asset prices, risk and other financial variables have been considered to obtain the rule with the most satisfactory performance. For instance, explorations on the role of exchange rates on the monetary transmission mechanism have been 
conducted by, among others, Taylor (2001), and Froyen and Guender (2018). Whilst studies by Bernanke and Gertler (2000), and Hafner and Lauwers (2015), among others, have investigated the central banks' responses to asset price movements. Furthermore, Taylor and Williams (2010) suggested that the exploration of alternative policy rules may need to involve the international linkages of monetary policy and the economies. Most of the previous studies that considered the role of capital flows have been focused on the indirect relationship between the financial flows and monetary policy via exchange rate pass-through. This might be due to the consideration of the volatile characteristic of these flows, so that the policymakers become more prudent before deciding whether it is necessary to react directly to these changes.

The episodes of large cross-border capital flows between economies are inevitable when the global financial system is more integrated, and capital is more mobile. In particular, following two severe crises episodes in Asia around 1997/1998 and the global financial crisis which occurred in major advanced economies in 2008/2009, there was a large increase in capital mobility from advanced to emerging economies. Among several key drivers of this phenomenon, the policy interest rate setting in developed economies has been claimed as one of the most significant factors behind this movement (Ahmed and Zlate 2014).

Motivated by the limited number of empirical studies that consider capital flows explicitly in the augmented Taylor rule, this study aims to contribute to the current discussions by exploring a potential alternative policy rule based on historical data, by considering the influence of capital flows explicitly in the policy objective. Here we expect to discover whether the central banks should respond to capital flow movements. To obtain a more comprehensive view on the role of capital flows from both sides, the foreign-owned (capital inflows) and the domestic-owned investment (capital outflows) are accommodated in separate estimations. Furthermore, following the literature, we also include other indicators like the exchange rates and international variables, covering the fed funds rate and the VIX volatility index.

The next section outlines the relevant literature, following this we describe the model and the data. We then analyse the results and finally we draw some conclusions and policy implications.

\section{Literature Review}

As proposed by Taylor (1993), the Taylor rule was intended to be a general guideline for the policymakers in deciding their interest rate. The specification of the rule ideally refers to the economic conditions prevalent in a particular country, resulting in the possibility of a different rule across economies. In recent studies, the extended version of the rule has been the focus of discussions, as it has empirically been outperforming the simple rule in capturing the economic conditions more accurately. The use of the Taylor rule as an appropriate approach to monetary policy decision making has been proven in many countries. Clarida et al. (1998) demonstrated the importance of the Taylor rule, by presenting empirical evidence from two groups of countries, which they called the G3 (US, Germany, Japan) and E3 (UK, Italy, France). A slightly different conclusion was drawn from both groups. While the central banks in the G3 countries are found to follow the forward-looking Taylor rule by adjusting the real interest rate to anticipated inflation, the E3 countries were more influenced by the German Bundesbank's monetary policy. A study by Gerlach and Schnabel (2000) also verified that monetary policy in the EMU countries followed the Taylor rule recommendation, between1990-1998. They found that the average interest rate movements were associated with the average output gaps and inflation. Moreover, Côté et al. (2004) tested a simple monetary policy rule for the Canadian economy and found that the Taylor rule appeared to be one of the most stable rules. Levin et al. (1999) also demonstrated that when the Taylor rule was suitably parameterised, it could robustly assist the conduct of monetary policy in the US. They applied the Taylor-type reaction function with interest rate smoothing and suggested that the results were relatively robust.

Although the empirical findings have suggested that the Taylor rule has been proven to perform well in some countries, there are also some criticisms of the rule. One of the recent criticisms was raised 
by Bernanke (2015), who suggested that although a modified Taylor rule had effectively described US monetary policy since the 1990s, it does not mean that this would automatically be the case in the future. Some of the reasons for this are related to the complexity of the underlying judgements of the Fed, which the simple Taylor rule does not cover. Besides that, in practice, the output gap measurement is complicated, where some assessments from the Fed are typically needed to supplement the rule. Svensson (2003) also pointed out several issues related to the Taylor rule, for instance there is a possibility that the Taylor rule will not be optimal in countries where other important variables exist, aside from inflation and the output gap. Thus, under certain conditions in some countries, the rule is possibly different from the optimal setting.

Similar comments on the Taylor rule's limitations were also raised by Hofmann and Bogdanova (2012) who mainly suggested that the traditional Taylor rule might insufficiently capture factors that are important for financial stability and the macroeconomic conditions. This can lead to downward bias on the policy rate during financial booms and upward bias during the bust periods. Moreover, the simple Taylor rule also has a weakness in capturing the role of other monetary policy instruments, such as changes in reserve requirements.

Greater awareness of the negative effects arising from particularly large capital flow reversals, adversely affecting the economy, has been developed recently, generating more recent specifications of the Taylor rule. These consider other important variables such as the exchange rate, asset prices, wealth indicators, interest rate spreads or credit aggregates, such as by Bernanke and Gertler (2000), Taylor (2001), Morley and Wei (2012), Froyen and Guender (2018), and Caporale et al. (2018). Taylor (2001) developed an augmented Taylor rule by taking into account the exchange rate in his original baseline rule. He explored the existence of the direct and indirect effect of the exchange rate on the interest rate. His findings suggested that although no direct impact was found on the policy rule, there is an indirect impact of the exchange rate on the interest rate setting. This effect, according to Taylor, may lead to less unpredictable fluctuations in the interest rates. Furthermore, his observation on several advanced economies lead to a conclusion that the model including the exchange rate outperformed the baseline rule in some countries such as France and Italy, although it was not the case for Germany. In the countries where the exchange rate matters, the rule implicates that the central bank needs to lower the interest rate when the exchange rate increases to higher than normal rates (appreciated), calling for an expansion in monetary policy.

Coeue (2017) assessed the basic relationship between the exchange rate and interest rate movements during the period 2005 to 2011. His analysis of the short-term and long-term interest rate suggested a strong correlation between the exchange rate and short-term interest rates, but not with the long-term interest rate differentials. However, near the end of 2011, the connection broke down, which was not surprising as it coincided with the use of unconventional monetary policies around that period. A recent assessment by Froyen and Guender (2018) confirmed the important role of the exchange rate in the Taylor rule. They proved that the optimal monetary policy becomes less aggressive when real exchange rate fluctuations are considered in the model specification, although only a small weight was assigned on this indicator. Therefore, they suggested that once the real exchange rate was incorporated, the performance of the rule was improved compared to the standard policy rule. Aizenman et al. (2008) investigated the role of the real exchange rate on policy formulations in inflation targeting (IT) for emerging economies. Evaluating the data of 16 emerging markets during the period 1989-2006, they concluded that inflation, as well as the real exchange rates are the most influential factors determining the decisions on policy rates in these economies. Moreover, they also found that the response of the policymakers to the real exchange rate was stronger in the more intensive commodity exporter countries.

Next, Lubick and Schorfheide (2007) focused their research on the responses of the policy authorities to the generic Taylor rule that accommodates, inflation, output, and the exchange rate movements. Applying the structural general equilibrium model to a small open economy using the 
Bayesian approach, their estimation results suggested different findings, where the central banks reacted to the nominal exchange rate in Canada and the UK, but not in Australia and New Zealand.

A further study on the Taylor rule has been concerned with the connection between monetary policy with risk indicators. Bekaert et al. (2013) for instance, noticed a strong co-movement between the real interest rates and VIX, which has been a popular measurement of risk aversion in the financial markets. Two components of VIX, the risk aversion and expected stock market volatility (representing the uncertainty) were analysed. This finding from US data during 1990-2010 suggested that both indicators were lessened by a lax monetary policy. In addition, Borio and Zhu (2012) also argued about the need to pay more attention to the link between monetary policy and the risk-taking channel, in line with transformations in the financial system and prudential regulation.

Past experience has proved that in reality, a simple monetary policy rule, given the robustness advantages, can work better than complex models or fully optimal rules (Taylor and Williams 2010). Recently, the search for a better and more robust policy rule has encouraged the policymakers to accommodate a wider model specification and the economic environment. Therefore, the exploration of alternative rules may need to involve international linkages in monetary policy and the economies. As yet, there are a limited number of papers that discuss the influence of international linkages in the rule, particularly one that considers capital flow dynamics directly in the model. The previous discussions mostly argued for the inclusion of its indirect effect on monetary policy via exchange rate pass-through. Froyen and Guender (2018) for example, described the need to re-examine the open economy Taylor rule, following changes in global financial markets after the crisis hit several advanced economies during 2007-2009. Around this period, some central banks from major economies, including the Federal Reserve decided to purchase a large number of assets and implement near-zero policy rates, which triggered massive capital movements to smaller economies. As a consequence, a currency appreciation was inevitable in some of the recipient economies. When the Fed started to adjust its policy rate back to normal levels, the policymakers were concerned with the possibility of a sudden fall in capital inflows and the opposite effect on the domestic currency. Therefore, he suggested that the central banks, in particular, in small open economies should add exchange rate stability as part of their policy goals. This argument has been supported by Blanchard et al. (2010) in his review of macroeconomic policy. He expressed the need to accommodate the exchange rate objective explicitly in the policy reaction function, in addition to the ultimate goal of achieving a stable output gap and inflation. Furthermore, Taylor (2001) suggested that the link between the interest rate and the exchange rate existed through capital market interactions.

A study by Dağlaroğlu et al. (2018) investigated how short-term capital flows have meant there is a need for innovative policy measures in a developing economy like Turkey. This paper was motivated by the volatility of capital flows which brought some challenges to domestic financial stability. The variable representing capital flows is approximated by a risk premium indicator using EMBI (JP Morgan Emerging Market Bond Index plus Turkey) and Credit Default Swap Spreads (CDS). They argued that a negative shock in the financial market may lead to an increase in the risk premium, which in turn may result in a devalued domestic currency and contribute to an increase in inflation via exchange rate pass-through. By splitting the observations into pre- and post-2010, they found a significant role from global financial factors, as represented by EMBI, and VIX in the augmented Taylor rule in the period after 2010, indicating that interest rate policy in Turkey has been influenced by these external indicators.

\section{Materials and Methods}

In Taylor (1993), John Taylor proposed a simple interest rate rule that focused on the adjustment of the central bank's short-term interest rate instrument as a response to the state of the economy. His original Taylor rule was expressed as a representative rule for monetary policy in the United States as:

$$
r_{t}=\pi_{t}+0.5 y_{t}+0.5\left(\pi_{t}-\pi^{*}\right)+r^{*}
$$


or in a more specific way when the target rate of inflation is assumed to be set at $2 \%$ it can be expressed as:

$$
r_{t}=\pi_{t}+0.5 y_{t}+0.5\left(\pi_{t}-2\right)+2
$$

where:

$r_{t}$ : the federal funds rate,

$r^{*}$ : the equilibrium real fed funds rate,

$\pi_{t}$ : the inflation rate,

$\pi^{*}$ : the target of inflation rate,

$y_{t}$ : the output gap, which represents the deviation of real GDP from the target.

Under this rule, the Federal Reserve should raise the interest rate when the inflation rate goes above a target of $2 \%$, or when the real GDP exceeds the trend GDP, so that the relationship between interest rates and both inflation and output is positive. It is also suggested that when there is no deviation from the target, or in other words when inflation and the real GDP meet the target, the policy rate is equal to $4 \%$, or in real terms is equal to $2 \%$. In this formula, Taylor argued that the $2 \%$ equilibrium real rate was close to the assumption of the steady-state growth rate of $2.2 \%$ in the US during that period. This size of response, according to Taylor, described the actual policy actions by the Federal Reserve, which was fairly accurate during those years.

Taylor and Williams (2010) suggested that it is important to evaluate the policy rules so as to identify the most relevant characteristics in the rules which are more robust to model specifications. Motivated by the original Taylor rule in Taylor (1993) and the related studies afterwards, we follow the literature in constructing our baseline and augmented policy rule. To capture the interest rate dynamics, we include the interest rate smoothing, represented by the lagged interest rate, in addition to the standard indicators (inflation and output gap) and other variables (exchange rates, fed funds rate, VIX, and capital flows) as in the equations below:

Baseline Taylor Rule

$$
r_{i, t}=f\left(\pi_{i, t}-\pi_{i, t}^{*}\right)+g y_{i, t}+\varepsilon_{i, t}
$$

Augmented Taylor Rule

$$
r_{i, t}=f\left(\pi_{i, t}-\pi_{i, t}^{*}\right)+g y_{i, t}+h e_{i, t}+k z_{i, t}+j c f_{i, t}+\varepsilon_{i, t}
$$

where

$r_{i, t}$ : the policy rate of the central bank;

$\pi_{i, t}$ : the inflation rate;

$y_{i, t}$ : the output gap, which shows the deviation of actual GDP from the potential GDP;

$\pi_{i, t}{ }^{*}$ : the inflation target set by the central bank;

$e_{i, t}$ : the exchange rate deviation from its long-term (trend) value;

$z_{i, t}$ : the set of extended variables, comprising the fed funds rate and the VIX volatility index;

$c f_{i, t}$ : the capital flows, corresponding to capital inflows or capital outflows, which will be separately estimated;

$\varepsilon_{i, t}$ : the error term.

In addition, our model specification also reveals that we consider both the domestic and international dimension. The latter is represented by two international factors: the fed funds rate and VIX volatility index, that symbolises the global risk appetite of the foreign investors. The connection between monetary policy and the risk indicator has been previously discussed, for example, by Bekaert et al. (2013), who found a strong co-movement between real interest rates and the VIX, as the proxy for the risk appetite of international investors. Additionally, a study in the US by Bruno and Shin (2015) discovered that the higher fed funds rate corresponds to greater risk aversion in the VIX. Besides 
that, Dağlaroğlu et al. (2018) found a significant role for VIX in the short-term monetary policy rate in Turkey.

Moreover, the dominant role of the US Dollar in international trade and finance within the global economy has encouraged the policymakers to pay more attention to the Federal Reserve's policy decision (Bernanke 2015). The previous experience has also shown how the interest rates of a major economic player like the fed funds rate (FFR) can have an influence on the direction of capital flows, for example, from advanced to emerging countries (Ahmed and Zlate 2014). Froyen and Guender (2018) also described the phenomenon of policy changes that took place following the financial crisis in 2007-2009. Around this period, some central banks from major economies, including the Federal Reserve decided to purchase a large number of assets and implement near-zero policy rates, which triggered massive capital movements to other economies. In addition, Takats and Vela (2014) among others also suggested that US monetary conditions have driven the policy rates, particularly in emerging economies. Moreover, they found a significant relationship between the long-term interest rate in the US with the long-term interest rates in emerging countries. The co-movement of those long-term interest rates was stronger following the global financial crisis periods.

All the models have been estimated using the Arellano-Bond approach to dynamic panels, to account for the interest rate smoothing that central banks conduct, such that interest rates partially adjust from one time period to the next. In addition, all models estimated with robust standard errors.

\subsection{Data}

According to the recent IMF database, up to now there are 38 potential countries from emerging and advanced economies that are currently listed as formal inflation targeters. Due to data availability, this study covers only 34 out of these 38 countries (along with the US data). Due to this reason, Albania, Khazakstan, Guatemala, and Serbia are not included in the sample. In addition to the countries that have adopted IT formally, as mentioned before, we also include the United States in the sample, as many studies of the Taylor rule have been done earlier on the United States. Moreover, the Federal Reserve has been constantly sending out signals of its inflation target to the public.

Under the IT framework, the central banks are required to announce their inflation target to the public. The inflation target data used in this study are only available once the country has started to implement the framework. Consequently, although the observation period is from 1990 to 2018, the length of observations in each country depends on the IT starting date, resulting in unbalanced observations. Some of the advanced countries started IT in the early 1990s. New Zealand was the first one to adopt the framework in 1990, followed by Canada in 1991, the United Kingdom in 1992, Australia and Sweden in 1993. The full list of countries included in our sample and their IT starting dates can be found in Table A1.

The dependent variable in our estimations are the policy rates, which refer to the central bank's policy rates in each country. The main source of this data is the Bank for International Settlements (BIS). However, for some countries, when they are not available, the data have been obtained from the central bank website in the individual countries. The other six variables used as the regressors are mainly gathered from the Bank for International Settlements (BIS), the International Monetary Fund (IMF): Balance of Payment (BOP), International Financial Statistics (IFS), and the World Bank database: World Development Indicators (WDI). Other sources are the central bank's websites, and the Chicago Board Options Exchange (CBOE) database.

Other than the VIX, which is stated in an index, other variables are measured either in percentage or percentage of GDP form, as shown in Table 1. The main variables in the equations (inflation, GDP, and REER) are calculated in gap measurement form. The GDP variable, which was originally measured in constant USD $(2010=100)$, is firstly converted into the log form before estimating its trend values using HP filters. Next, the GDP gap is calculated by subtracting the trend (long term) value of GDP that has been estimated using the HP filters from the real GDP. Once the difference is obtained, the latter step is dividing the gap by the trend of GDP and multiplying it by $100 \%$ to get the GDP gap percentage. 
A similar technique was also applied to compute the Real Effective Exchange Rates (REER) gap. Finally, for the inflation gap, it is simply the deduction of the inflation target which has been set by the central banks from the actual inflation rates.

Table 1. List of Variables and Data Sources.

\begin{tabular}{cccc}
\hline No & Variable & Source & Unit \\
\hline 1 & Policy Rates & Bank for International Settlements (BIS), & Percent \\
& Central Bank Websites & \\
2 & Inflation Gap & World Development Indicators (WDI), & Percent \\
3 & GDP Gap & World Development Indicators (WDI), & Percent \\
4 & REER Gap & Bank for International Settlements (BIS) & Porld Development Indicators (WDI), BIS \\
5 & Capital Inflows and Outflows & Balance of Payments (BOP), International & Percent of \\
6 & Fed Fund Rate & Financial Statistics (IFS) & GDP \\
7 & VIX & International Financial Statistics (IFS) & Percent \\
& & Chicago Board Options Exchange (CBOE) & Index \\
\hline
\end{tabular}

In line with the main objective in this study, the Taylor rule extension involves including capital flows variables. We focus the analysis on 2 types of capital flow categories, namely direct investment and portfolio investment. Other investment is excluded from the analysis because this type of flow is typically very volatile and containing some residual category which covers the positions and transactions other than those counted in direct investment, portfolio investment, financial derivatives and employee stock options, and reserve assets ${ }^{1}$. Additionally, the last three categories are not included since they are not significant.

In addition to the analysis of capital inflows, we also estimate the Taylor rule with the capital outflows variable. As described by the IFS, capital inflows refer to the flows on the liabilities side of the BOP (which corresponds to the "foreign-owned" investment), while capital outflows denote the assets side (which relates to the "domestic-owned" investment) ${ }^{2}$. Capital inflows and outflows are measured as the percentage of GDP; thus, we divide its current values from the original data by the nominal GDP. The summary statistics of all variables included in the estimations are presented in Table A2 in the Appendix A.

\subsection{Unit Root Test}

This study uses the Phillip Perron and Augmented Dicky-Fuller (ADF) tests for unbalanced panel data to test for the stationarity of all variables. A time trend is included in the unit root test to account for the trend stationarity. Based on these tests, all variables are stationary in levels, as we can reject the null hypothesis of all panels contain unit roots. The test results are presented in Table A3 in the Appendix A.

\section{Results and Discussion}

\subsection{Taylor Rule Model with Capital Inflows}

The policymaker's behaviour that follows a typical Taylor rule can be reflected by their response to the deviations in inflation and the output gap from their targets. Using annual unbalanced panel data

1 See the Balance of Payments and International Investment Position Manual (BPM6 2014) for further definition of all types of capital flows.

2 The capital flows data, based on the IFS standard code used in this paper are: Direct Investment, Liabilities (BFDLXF_BP6_USD), Portfolio Investment, Liabilities (BFPLXF_BP6_USD), Direct Investment, Assets (BFDA_BP6_USD), and Portfolio Investment, Assets (BFPA_BP6_USD). 
over the period 1990-2018, we present evidence on the baseline Taylor rule model of the IT economies, to represent the original central bank monetary policy as in Taylor (1993). In this scenario, to capture the interest rate dynamics, we accommodate the lagged interest rate in the regressors.

Table 2 below reports the estimation of the baseline model under 2 scenarios: before and after controlling for the global financial crisis 2008-2009, as represented by dummy crisis variables on the right of the table. Although the results in both tables are similar, the addition of the crisis dummy variable is noteworthy, since its parameter estimate is strongly significant in all samples. Overall, we obtained the expected estimation results in this sample category. The sign of the parameter estimates of the variables is in line with the Taylor rule theory. Moreover, we obtained consistent estimation results with the previous panel empirical studies in terms of the important role of indicators on the policy rule. The sign and magnitudes of parameter estimates overall are partly in line with, for example, Aizenman et al. (2008), Ghosh et al. (2016), and Castro (2011). As predicted, the smoothing variable, represented by the first lag of the interest rate, shows a very substantial influence on the setting of monetary policy in our sample. The lagged interest rate was also significant and positive, with a value below one, as in other studies such as Clarida et al. (1998) and Hofmann and Bogdanova (2012), who also had positively signed and significant coefficients on the inflation and output gap coefficients. The output gap has consistently been considered as one of the major factors by the central bank when setting their interest rates. In the model without the dummy crisis variable, the inflation gap parameter estimate is also statistically significant, suggesting a role for inflation in setting the policy interest rate in the IT economies when the financial crisis is accounted for. This finding is not totally unexpected, although they have both, in fact, adopted the IT. For instance, after the financial crisis, the Bank of England's response to inflation has been reduced substantially and become no longer significant. Furthermore, during the crisis regime, their financial stress variable becomes very influential. Even though the UK monetary policy rule had changed during the crisis, empirical estimations could not capture the reasons for the changes, as it will also call for joint estimations and examination on the relationship of the aggregate demand and supply.

Table 2. The Baseline Taylor Rule (Model 1).

\begin{tabular}{ccc}
\hline Variable & Without GFC Dummy Variable & With GFC Dummy Variable \\
\hline Lag Policy Rates & $0.594^{* * *}$ & $0.605^{* *}$ \\
& $(0.06)$ & $(0.06)$ \\
\hline Inflation Gap & $0.389^{* * *}$ & $0.451^{* * *}$ \\
& $(0.11)$ & $(0.11)$ \\
\hline GDP Gap & $2.737^{* * *}$ & $2.599^{* * *}$ \\
& $(0.77)$ & $(0.80)$ \\
\hline GFC Dummy & & $-1.609^{* * *}$ \\
& $1.801^{* * *}$ & $(0.23)$ \\
\hline Constant & $(0.37)$ & $1.879^{* * *}$ \\
& 490 & $(0.35)$ \\
\hline Observations & 0.00 & 490 \\
\hline Prob $>\chi^{2}$ & 0.00 \\
\hline
\end{tabular}

Notes: Numbers in parentheses report the standard errors. ${ }^{* *}, * * *$ indicate the statistical significance at the $5 \%$, and $1 \%$, respectively. All models are estimated with robust standard errors and passed the overidentifying restrictions test at $1 \%$ level of significance.

The next section emphasizes the cross-border investment flows that are associated with foreign financial flows. Therefore, our main discussion involves the liabilities (inflows), as well as the asset (outflows) side of direct and portfolio investment in the Balance of Payment (BOP). On the liabilities side, positive capital inflows are associated with more foreign investment to the receiving economies. Whilst, negative capital inflows indicate a reversal of foreign investment from the receiving economies. 
This is also similar for capital outflows. Given the high correlation between capital inflows and outflows, we proceed with the Taylor rule estimations with capital outflows separately in the next section.

As in the baseline estimation results, the output in the table below displays the estimates from our augmented Taylor rule model, once the global financial crisis (GFC) dummy variable has been taken into account. Because the crisis dummy variable always shows a strong influence in all models, this result will be our main reference. Moreover, since the global financial crisis in 2008-2009, the movement of capital flows across countries has led to increased awareness by policymakers around the world. The episodes of large capital inflows and outflows may have particularly affected their policy decisions. As we extend the original Taylor rule model in Table 3, we get consistent results with the baseline model. For instance, the inflation gap indicator is influential in all extended models. As expected, the output gap has a substantial role in the central bank's interest rates decision, although it is no longer significant in Models 4-5, once we control for the global variables in the model. Moreover, the exchange rates (REER) indicator is considered as an important variable in interest rate setting in our sample. Among others, Aizenman et al. (2008) and Taylor (2000) implied that the exchange rate fluctuations have been more important in emerging economies, compared to advanced countries, which make up the majority of the sample. The significant finding for the REER supports previous studies that noted the important role of exchange rates for monetary policy decision making in IT emerging economies. In terms of the sign and magnitude of the REER, the result is comparable with Markov and Nitschka (2013) and Ghosh et al. (2016). As expected, the coefficient on the REER gap has a negative sign, indicating that when the exchange rate appreciation becomes too high, the central banks in emerging economies are expected to cut the interest rates. This finding is also in line with the rule of thumb interpretation from Obstfeld and Rogoff (1995). This might be due to emerging economies generally have a greater concern for exchange rate fluctuations than most advanced economies, as they tend to be more volatile. Furthermore, they also mentioned that while several studies found that in many policy evaluation models, the exchange rate has been a significant measure in the transmission mechanism, others have observed that the central banks had not reacted substantially to this variable.

Table 3. The Augmented Taylor Rule with Capital Inflows and GFC Dummy.

\begin{tabular}{|c|c|c|c|c|}
\hline Variable & Model 2 & Model 3 & Model 4 & Model 5 \\
\hline Lag Policy Rates & $\begin{array}{c}0.603 * * * \\
(0.06)\end{array}$ & $\begin{array}{c}0.599 * * * \\
(0.06)\end{array}$ & $\begin{array}{c}0.463^{* * *} \\
(0.07)\end{array}$ & $\begin{array}{c}0.459^{* * *} \\
(0.07)\end{array}$ \\
\hline Inflation Gap & $\begin{array}{c}0.454^{* * *} \\
(0.11)\end{array}$ & $\begin{array}{c}0.428 * * * \\
(0.10)\end{array}$ & $\begin{array}{c}0.451 \text { *** } \\
(0.10)\end{array}$ & $\begin{array}{c}0.418^{* * *} \\
(0.09)\end{array}$ \\
\hline GDP Gap & $\begin{array}{c}2.385^{* * *} \\
(0.81)\end{array}$ & $\begin{array}{c}3.356 * * * \\
(0.88)\end{array}$ & $\begin{array}{l}0.152 \\
(0.97)\end{array}$ & $\begin{array}{l}1.137 \\
(1.06)\end{array}$ \\
\hline REER Gap & & $\begin{array}{c}-0.046^{* * *} \\
(0.02)\end{array}$ & & $\begin{array}{c}-0.048^{* * *} \\
(0.02)\end{array}$ \\
\hline Capital Inflows & $\begin{array}{c}0.031^{* * *} \\
(0.01)\end{array}$ & $\begin{array}{c}0.032 * * * \\
(0.01)\end{array}$ & $\begin{array}{c}0.029 * * * \\
(0.01)\end{array}$ & $\begin{array}{c}0.031^{* * *} \\
(0.01)\end{array}$ \\
\hline Fed Fund Rate & & & $\begin{array}{c}0.362^{* * *} \\
(0.07)\end{array}$ & $\begin{array}{c}0.364^{* * *} \\
(0.07)\end{array}$ \\
\hline VIX Index & & & $\begin{array}{c}0.050 * * * \\
(0.02)\end{array}$ & $\begin{array}{c}0.053^{* * *} \\
(0.02)\end{array}$ \\
\hline GFC Dummy & $\begin{array}{c}-1.617^{* * *} \\
(0.24)\end{array}$ & $\begin{array}{c}-1.606^{* * *} \\
(0.23)\end{array}$ & $\begin{array}{c}-1.480^{* * *} \\
(0.33)\end{array}$ & $\begin{array}{c}-1.493^{* * *} \\
(0.30)\end{array}$ \\
\hline Constant & $\begin{array}{c}1.687^{* * *} \\
(0.36)\end{array}$ & $\begin{array}{c}1.697^{* * *} \\
(0.37)\end{array}$ & $\begin{array}{c}0.893^{* * *} \\
(0.32)\end{array}$ & $\begin{array}{c}0.843^{* *} \\
(0.33)\end{array}$ \\
\hline Observations & 479 & 479 & 479 & 479 \\
\hline Prob $>\chi^{2}$ & 0.00 & 0.00 & 0.00 & 0.00 \\
\hline
\end{tabular}

Notes: Numbers in parentheses report the standard errors. ${ }^{* *}, * * *$ indicate the statistical significance at the $5 \%$, and $1 \%$, respectively. All models are estimated with robust standard errors and passed the overidentifying restrictions test at $1 \%$ level of significance. 
After adding the capital flows variable into the augmented Taylor rule in Models 2-5, we can observe that the central banks in these economies consider this indicator in determining their policy rates. The positive sign indicates that when the economy is experiencing larger capital inflows, the policymaker is responding by setting higher interest rates.

Furthermore, focusing on the models with global indicators, which are represented by the Fed Fund Rate (FFR) and the VIX index in Models 4 and 5, the central banks show a strong reaction to the changes in the both variables. This result demonstrates how important the US monetary policy is for the central banks' decision in other developed economies in our sample. Given the fact that the US is one of the dominant economic players which can influence policy setting in other countries, this finding is as expected. The positive sign on the FFR estimated parameter indicates that the countries tend to increase their policy rates when the Fed raises the FFR. Furthermore, an increased financial risk, as indicated by a higher VIX index, will be followed by an increase in the interest rates by the central banks. This finding is in line with a previous study by Dağlaroğlu et al. (2018) who found the significant role of VIX for monetary policy setting in the case of Turkey. The importance of the risk consideration in policy decision making was previously suggested by for example Borio and Zhu (2012). They emphasised the need to pay more attention to the link between monetary policy and the risk-taking channel.

Although we refer to our results mainly based in the Table 3 as mentioned earlier, for a comparison purpose, we also present the estimation results before controlling for the GFC episodes. Overall, there are no significant differences between the two findings. Here we can see that when we are not taking into account the crisis variable, the policymakers no longer consider the global uncertainty through the financial market volatility indicator (VIX index). In addition, compared to the output in Table 3, the monetary policy response is slightly smaller on capital inflow dynamics in Table 4 . It indicates that when the policymakers do not consider the crisis indicator in their monetary policy, they still respond to capital inflows, but to a lesser degree.

Table 4. The Augmented Taylor Rule with Capital Inflows (without GFC variable).

\begin{tabular}{ccccc}
\hline Variable & Model 2 & Model 3 & Model 4 & Model 5 \\
\hline Lag Policy Rates & $0.591^{* * *}$ & $0.587^{* * *}$ & $0.435^{* * *}$ & $0.431^{* * *}$ \\
& $(0.06)$ & $(0.06)$ & $(0.07)$ & $(0.07)$ \\
\hline Inflation Gap & $0.394^{* * *}$ & $0.367^{* * *}$ & $0.444^{* * *}$ & $0.412^{* * *}$ \\
& $(0.11)$ & $(0.10)$ & $(0.10)$ & $(0.09)$ \\
\hline GDP Gap & $2.555^{* * *}$ & $3.573^{* * *}$ & 0.367 & 1.316 \\
& $\left(0.77^{* *}\right.$ & $(0.86)$ & $(0.98)$ & $(1.10)$ \\
\hline REER Gap & & $-0.049^{* * *}$ & & $-0.047^{* *}$ \\
& & $(0.02)$ & & $(0.02)$ \\
\hline Capital Inflows & $0.029^{* * *}$ & $0.030^{* * *}$ & $0.024^{* * *}$ & $0.025^{* * *}$ \\
& $(0.01)$ & $(0.01)$ & $(0.01)$ & $(0.01)$ \\
\hline Fed Fund Rate & & & $0.436^{* * *}$ & $0.439^{* * *}$ \\
& & & $(0.07)$ & $(0.06)$ \\
\hline VIX Index & & 0.018 & 0.021 \\
& & & $(0.01)$ & $(0.01)$ \\
\hline Constant & $1.630^{* * *}$ & $1.641^{* * *}$ & $1.424^{* * *}$ & $1.381^{* * *}$ \\
& $(0.37)$ & $(0.38)$ & $(0.35)$ & $(0.35)$ \\
\hline Observations & 479 & 479 & 479 & 479 \\
\hline Prob $>\chi^{2}$ & 0.00 & 0.00 & 0.00 & 0.00 \\
\hline
\end{tabular}

Notes: Numbers in parentheses report the standard errors $* *, * * *$ indicate the statistical significance at the $5 \%$, and $1 \%$, respectively. All models are estimated with robust standard errors and passed the overidentifying restrictions test at $1 \%$ level of significance. 


\subsection{Taylor Rule Model with Capital Outflows}

The recent literature has emphasised the large movements of capital flows across countries. Massive cross-border capital flows especially occurred when the global financial crisis hit some of the most advanced countries around 2008-2009. Furthermore, managing capital outflows is equally important for the authorities in order to minimize the risk of a massive investment shrinkage in the domestic economy. To complete the analysis, this section describes the results from the augmented Taylor rule using the capital outflows variable, in addition to some other variables as used in the capital inflows analysis. Overall, the estimation outputs from these models suggests almost similar findings to the ones from the Taylor rule with capital inflows.

As in the previous section, we start the estimation by controlling for the global financial crisis dummy variable as in Table 5, and then compare it with the output in Table 6. As expected, the estimation results for the other variables in these models are analogous with the ones from the Taylor rule with capital inflows. In addition to the lagged interest rates, the inflation gap, output gap (except in models 4 and 5), capital outflows and global variables which are represented by the global interest rate (FFR) and the VIX index are found to be influential for interest rate setting in our sample, once the GFC variable is taken into account in the models.

Table 5. The Augmented Taylor Rule with Capital Outflows and GFC Dummy.

\begin{tabular}{|c|c|c|c|c|}
\hline Variable & Model 2 & Model 3 & Model 4 & Model 5 \\
\hline Lag Policy Rates & $\begin{array}{c}0.641^{* * *} \\
(0.05)\end{array}$ & $\begin{array}{c}0.633^{* * *} \\
(0.05)\end{array}$ & $\begin{array}{c}0.483^{* * *} \\
(0.07)\end{array}$ & $\begin{array}{c}0.477^{* * *} \\
(0.07)\end{array}$ \\
\hline Inflation Gap & $\begin{array}{c}0.402^{* * *} \\
(0.12)\end{array}$ & $\begin{array}{c}0.387^{* * *} \\
(0.12)\end{array}$ & $\begin{array}{c}0.419 \text { *** } \\
(0.11)\end{array}$ & $\begin{array}{c}0.401^{* * *} \\
(0.10)\end{array}$ \\
\hline GDP Gap & $\begin{array}{c}1.956^{* *} \\
(0.87)\end{array}$ & $\begin{array}{c}2.778^{* * *} \\
(0.91)\end{array}$ & $\begin{array}{c}-0.245 \\
(0.96)\end{array}$ & $\begin{array}{l}0.520 \\
(1.01)\end{array}$ \\
\hline REER Gap & & $\begin{array}{c}-0.036^{* *} \\
(0.01)\end{array}$ & & $\begin{array}{c}-0.034 \\
(0.02)\end{array}$ \\
\hline Capital Outflows & $\begin{array}{c}0.035^{* * *} \\
(0.01)\end{array}$ & $\begin{array}{c}0.035^{* * *} \\
(0.01)\end{array}$ & $\begin{array}{c}0.027^{* * *} \\
(0.01)\end{array}$ & $\begin{array}{c}0.027^{* * * *} \\
(0.01)\end{array}$ \\
\hline Fed Fund Rate & & & $\begin{array}{c}0.361^{* * *} \\
(0.07)\end{array}$ & $\begin{array}{c}0.363^{* * *} \\
(0.07)\end{array}$ \\
\hline VIX Index & & & $\begin{array}{c}0.049 * * * \\
(0.02)\end{array}$ & $\begin{array}{c}0.051^{* * *} \\
(0.02)\end{array}$ \\
\hline GFC Dummy & $\begin{array}{c}-1.525^{* * *} \\
(0.22)\end{array}$ & $\begin{array}{c}-1.542^{* * *} \\
(0.22)\end{array}$ & $\begin{array}{c}-1.316^{* * * *} \\
(0.30)\end{array}$ & $\begin{array}{c}-1.346^{* * *} \\
(0.29)\end{array}$ \\
\hline Constant & $\begin{array}{c}1.488^{* * *} \\
(0.31)\end{array}$ & $\begin{array}{c}1.525^{* * *} \\
(0.32)\end{array}$ & $\begin{array}{c}0.754^{* * *} \\
(0.27)\end{array}$ & $\begin{array}{c}0.748^{* *} \\
(0.29)\end{array}$ \\
\hline Observations & 459 & 459 & 459 & 459 \\
\hline Prob $>\chi^{2}$ & 0.00 & 0.00 & 0.00 & 0.00 \\
\hline
\end{tabular}

Notes: Numbers in parentheses report the standard errors. ${ }^{* *}, * * *$ indicate the statistical significance at the $5 \%$, and $1 \%$, respectively. All models are estimated with robust standard errors and passed the overidentifying restrictions test at $1 \%$ level of significance.

As the main interest in this study, we found that capital outflows are as important as capital inflows for monetary policy setting in these countries. The positive sign indicates that the central banks respond to the increasing capital outflows by raising interest rates. A possible explanation might be related to the central bank policy to curtail sudden increases in capital outflows from the domestic economy. 
As a robustness test, we also estimated the models using the OLS estimator for the quarterly time series data from 2000q3-2018q3 for the US as this had a plentiful amount of capital flow data. The results are presented in Table 7 below. In terms of capital outflows, there is little evidence of this factor influencing the US interest rate, although capital inflows do have a significant effect, this may be due to their effects on domestic inflation, which are both significant. Interestingly, the main determinant of interest rates in the US appears to be the VIX index. Given the importance of the financial crisis to the US economy over recent times, it is clear that financial risk is an important consideration when determining the US interest rate.

Table 6. The Augmented Taylor Rule with Capital Outflows.

\begin{tabular}{ccccc}
\hline Variable & Model 2 & Model 3 & Model 4 & Model 5 \\
\hline Lag Policy Rates & $0.620^{* * *}$ & $0.612^{* * *}$ & $0.449^{* * *}$ & $0.441^{* * *}$ \\
& $(0.06)$ & $(0.06)$ & $(0.07)$ & $(0.07)$ \\
\hline Inflation Gap & $0.362^{* * *}$ & $0.349^{* * *}$ & $0.429^{* * *}$ & $0.414^{* * *}$ \\
& $(0.12)$ & $(0.12)$ & $(0.11)$ & $(0.10)$ \\
\hline GDP Gap & $1.961^{* *}$ & $2.753^{* * *}$ & -0.270 & 0.403 \\
& $(0.81)$ & $(0.84)$ & $(0.90)$ & $(0.95)$ \\
\hline REER Gap & & $-0.035^{* * *}$ & & -0.031 \\
& & $(0.02)$ & & $(0.02)$ \\
\hline Capital Outflows & $0.035^{* *}$ & $0.035^{* * *}$ & $0.024^{* * *}$ & $0.024^{* * *}$ \\
& $(0.01)$ & $(0.01)$ & $(0.01)$ & $(0.01)$ \\
\hline Fed Fund Rate & & & $0.435^{* * *}$ & $0.439^{* * *}$ \\
& & & $(0.07)$ & $(0.06)$ \\
\hline VIX Index & & $0.022^{*}$ & $0.023^{*}$ \\
& & & $(0.01)$ & $(0.01)$ \\
\hline Constant & $1.452^{* * *}$ & $1.491^{* * *}$ & $1.215^{* * *}$ & $1.222^{* * *}$ \\
& $(0.34)$ & $(0.35)$ & $(0.28)$ & $(0.29)$ \\
\hline Observations & 459 & 459 & 459 & 459 \\
\hline Prob > $\chi^{2}$ & 0.00 & 0.00 & 0.00 & 0.00 \\
\hline
\end{tabular}

Notes: Numbers in parentheses report the standard errors. ${ }^{*}, * * * * *$ indicate the statistical significance at the $10 \%$, $5 \%$, and $1 \%$, respectively. All models are estimated with robust standard errors and passed the overidentifying restrictions test at $1 \%$ level of significance.

Table 7. The Augmented Taylor Rule with Capital Inflows and Outflows Using the US Data.

\begin{tabular}{ccccccc}
\hline \multirow{2}{*}{ Variable } & \multicolumn{3}{c}{ Inflows } & \multicolumn{3}{c}{ Outflows } \\
\cline { 2 - 7 } & Coef. & Robust SE & $\boldsymbol{t}$-Test & Coef. & Robust SE & $\boldsymbol{t}$-Test \\
\hline Lag Policy Rates & $0.784^{* * *}$ & 0.054 & 14.57 & $0.843^{* * *}$ & 0.044 & 19.04 \\
Inflation Gap & $0.099^{* *}$ & 0.049 & 2.02 & $0.101^{*}$ & 0.053 & 1.89 \\
GDP Gap & 0.569 & 1.582 & 0.36 & 1.406 & 1.726 & 0.81 \\
REER Gap & $0.04^{*}$ & 0.022 & 1.82 & 0.033 & 0.02 & 1.62 \\
Capital Flows & $0.080^{* *}$ & 0.031 & 2.55 & 0.023 & 0.038 & 0.63 \\
VIX Index & $-0.028^{* *}$ & 0.01 & 2.9 & $-0.026^{* *}$ & 0.01 & -2.76 \\
Constant & 0.31 & 0.226 & 1.37 & $0.597^{* * *}$ & 0.189 & 3.16 \\
\hline
\end{tabular}

Notes: ${ }^{*}, * * * * *$ indicate the statistical significance at the $10 \%, 5 \%$ and $1 \%$, respectively. All models are estimated with robust standard errors. 


\section{Conclusions}

Taylor and Williams (2010) suggested that the exploration of alternative policy rules may need to involve the international linkages of monetary policy and economies. However, there are a limited number of papers that discuss the influence of international linkages on the rule, particularly the ones that considers capital flow dynamics explicitly in the model. When they are discussed, the literature has tended to focus on the indirect effect via exchange rate pass-through. Moreover, Taylor (2003) indicated the need to consider a rule-based monetary policy, even though it serves as a general guideline for the policymakers. He implied that the recent phenomena of increasing capital flows and exchange rate volatility have been closely related to changes in policy orientation in some major advanced economies, when the rules-based policy shifted to unconventional monetary policy.

Motivated by this experience, this study aims to contribute to the current policy rule discussions by exploring a potential alternative model that considers the influence of capital flows as one of the policy objectives. Using this empirical approach, we expect to find whether the central banks should explicitly respond to capital flow dynamics. To fulfil this purpose, we analyse the interest rate setting behaviour of monetary policymakers in 34 inflation targeting (IT) countries over the period 1990-2018.

Using the Arellano Bond estimator, we can summarize our findings from the Taylor rule estimation as follows. Firstly, as in studies such as Clarida et al. (1998) and Hofmann and Bogdanova (2012), we also had positively signed and significant coefficients on the inflation and output gap coefficients. So, as expected, when inflation exceeds its target rate or the output gap is above the long-run trend, interest rates are increased to reduce aggregate demand in the economy. In addition to the lag of the policy rates and inflation gap, the output gap has consistently been considered as one of the major factors by the central bank when setting their interest rates. The positive sign on the coefficients implies that an increase in the output gap produces a rise in the central banks' policy rates. However, once we add the global indicators like FFR and the VIX index, the output gap is not as influential. The exchange rate indicator (REER) is also considered as an important variable in interest rate setting in our sample. This finding is not totally a surprise. Among others, Aizenman et al. (2008) and Taylor (2000) suggested that the exchange rate fluctuations have been important to monitor in emerging economies, which make up much of the sample. This result reflects the previous interpretations from Obstfeld and Rogoff (1995).

Second, accommodating the global variables in the models, we found that only FFR is consistently important for the policymakers, whilst the global financial market volatility (VIX) is mostly significant in the models with no crisis indicator. Third, as our main point of interest in this study, we found that the interest rate setting in IT countries is significantly influenced by both capital inflows and outflows.

Overall, our empirical results confirm a potential to involve capital flow dynamics in the monetary policy setting, as an alternative policy rule. Based on this finding, we expect to fill the gap in the empirical literature by incorporating the international linkages of monetary policy and economies as suggested by Taylor and Williams (2010).

Author Contributions: Conceptualization, T.A. and B.M.; methodology, T.A. and B.M.; software, T.A.; formal analysis, T.A. and B.M.; investigation, T.A.; writing, T.A. and B.M.; All authors have read and agreed to the published version of the manuscript.

Funding: This research received no external funding.

Acknowledgments: We would like to thank Chris Martin for his helpful comments, the usual disclaimer applies.

Conflicts of Interest: The authors declare no conflict of interest. 


\section{Appendix A}

Table A1. List of Countries and IT Adoption Dates.

\begin{tabular}{cccccc}
\hline No & $\begin{array}{c}\text { Advanced } \\
\text { Economies }\end{array}$ & $\begin{array}{c}\text { IT Adoption } \\
\text { Date }\end{array}$ & No & Emerging Economies & $\begin{array}{c}\text { IT Adoption } \\
\text { Date }\end{array}$ \\
\hline 1 & Australia & 1993 & 1 & Armenia & 2006 \\
2 & Canada & 1991 & 2 & Brazil & 1999 \\
3 & Japan & 2013 & 3 & Chile & 1999 \\
4 & Korea & 2000 & 4 & Colombia & 1999 \\
5 & New Zealand & 1990 & 5 & Czech Republic & 1997 \\
6 & Norway & 2001 & 6 & Dominican Republic & 2012 \\
7 & Russia & 2015 & 7 & Georgia & 2009 \\
8 & Sweden & 1993 & 8 & Ghana & 2007 \\
9 & United Kingdom & 1992 & 9 & Hungary & 2001 \\
10 & United States & 1996 & 10 & India & 2015 \\
& & & 11 & Indonesia & 2005 \\
& & & 12 & Israel & 1997 \\
& & & Mexico & 2001 \\
& & & 13 & Moldova & 2013 \\
& & & 15 & Paraguay & 2011 \\
& & & 16 & Peru & 2002 \\
& & & 17 & Philippines & 2002 \\
& & & Poland & 1999 \\
& & & Romania & 2005 \\
& & & South Africa & 2000 \\
& & & Thailand & 2000 \\
& & & Turkey & 2006 \\
& & & Uganda & 2011 \\
& & & 23 & Uruguay & 2007 \\
\hline
\end{tabular}

Source: BIS, central bank website.

Table A2. Summary Statistics.

\begin{tabular}{cccccc}
\hline Variable & N & Mean & SD & Min & Max \\
\hline Policy Rates & 558 & 5.45 & 4.30 & -0.50 & 26.00 \\
Inflation Gap & 559 & 0.51 & 2.36 & -6.94 & 14.25 \\
GDP Gap & 559 & 0.001 & 0.10 & -0.31 & 0.73 \\
REER Gap & 559 & -0.22 & 6.26 & -23.52 & 23.46 \\
Capital Inflows & 547 & 5.91 & 5.83 & -48.28 & 51.51 \\
Capital Outflows & 524 & 3.86 & 6.72 & -51.57 & 53.54 \\
Fed Funds Rate & 559 & 1.77 & 1.99 & 0.07 & 7.31 \\
VIX & 559 & 19.62 & 6.78 & 11.04 & 40.00 \\
\hline
\end{tabular}

Table A3. Augmented Dicky-Fuller and Philip Perron Unit Root Test Results.

\begin{tabular}{ccccc}
\hline \multirow{2}{*}{ Variable } & \multicolumn{2}{c}{ ADF } & \multicolumn{2}{c}{ Philip Perron } \\
\cline { 2 - 5 } & Statistic & $p$-Value & Statistic & $p$-Value \\
\hline Policy Rates & -6.26 & 0.00 & -4.64 & 0.00 \\
Inflation Gap & -8.81 & 0.00 & -8.42 & 0.00 \\
Output Gap & -3.27 & 0.00 & -3.38 & 0.00 \\
REER Gap & -5.18 & 0.00 & -2.83 & 0.00 \\
Capital Inflows & -1.26 & 0.10 & -8.85 & 0.00 \\
Capital Outflows & -6.09 & 0.00 & -11.19 & 0.00 \\
Fed Fund Rate (FFR) & -5.23 & 0.00 & -1.62 & 0.05 \\
Volatility Index (VIX) & -8.80 & 0.00 & -4.79 & 0.00 \\
\hline
\end{tabular}

Notes: H0: All panels contain unit roots; Ha: At least one panel is stationary; a trend term is included to account for the trend stationarity; the stationarity test is based on the inverse normal (Z) statistics. 


\section{References}

Ahmed, Shaghil, and Andrei Zlate. 2014. Capital Flows to Emerging Market Economies: A Brave New World? Journal of International Money and Finance 58: 221-48. [CrossRef]

Aizenman, Joshua, Michael Hutchison, and Ilan Noy. 2008. Inflation Targeting and Real Exchange Rates in Emerging Markets. NBER Working Paper No. 14561. Cambridge: NBER.

Bekaert, Geert, Maria Hoerova, and Marco Duca Lo. 2013. Risk, Uncertainty and Monetary Policy. Journal of Monetary Economics 60: 771-88. [CrossRef]

Bernanke, Ben. 2015. Federal Reserve Policy in an International Context. In 16th Jacques Polak Annual Research Conference Hosted by the IMF. Washington, DC: IMF.

Bernanke, Ben, and Mark Gertler. 2000. Monetary Policy and Asset Price Volatility. NBER Working Paper No. 7559. Cambridge: NBER.

Blanchard, Olivier, Ariccia Giovanni, and Mauro Paolo. 2010. Journal of Money, Credit and Banking 42: 199-215. [CrossRef]

Borio, Claudio, and Haibin Zhu. 2012. A Missing Link in the Transmission Mechanism? Journal of Financial Stability 8: 236-51. [CrossRef]

BPM6. 2014. BPM6 Compilation Guide-International Monetary Fund. Available online: https://www.imf.org/ external/pubs/ft/bop/2014/pdf/guide.pdf (accessed on 28 June 2020).

Bruno, Valentina, and Hyun Shin. 2015. Policy. Journal of Monetary Economics 71: 119-32. [CrossRef]

Caporale, Guglielmo, Mohamad Helmi, Abdurrahman Çatık, Faek Menla Ali, and Coskun Akdeniz. 2018. Monetary Policy Rules in Emerging Countries: Is There an, Augmented Nonlinear Taylor Rule? Economic Modelling 72: 306-19. [CrossRef]

Castro, Vitor. 2011. Can Central Banks' Monetary Policy be Described by A Linear (Augmented) Taylor Rule or by A Nonlinear Rule? Journal of Financial Stability 7: 228-46. [CrossRef]

Clarida, Richard, Jordi Galí, and Mark Gertler. 1998. Monetary Policy Rules in Practice Some International Evidence. European Economic Review 42: 1033-67. [CrossRef]

Coeue, Benoit. 2017. Monetary Policy, Exchange Rates and Capital Flows. In The 18th Jacques Polak Annual Research Conference by IMF. Washington, DC: ECB, pp. 1-16.

Côté, Denise, John Kuszczak, Jean-Paul Lam, Ying Liu, and Pierre St-Amant. 2004. The Performance and Robustness of Simple Monetary Policy Rules in Models of the Canadian Economy. Canadian Journal of Economics 37: 978-98. [CrossRef]

Dağlaroğlu, Tolga, Baki Demirel, and Syed Mahmud. 2018. Monetary Policy Implications of Short-term Capital Flows in Turkey. Empirica 45: 747-63. [CrossRef]

Froyen, Richard, and Alfred Guender. 2018. A Re-Assessment. Economic Modelling 73: 140-51. [CrossRef]

Gerlach, Stefan, and Gert Schnabel. 2000. The Taylor Rule and Interest Rates in the EMU Area. Economics Letters 67: 165-71. [CrossRef]

Ghosh, Atish, Jonathan Ostry, and Marcos Chamon. 2016. Two Targets, Two Instruments: Monetary and Exchange Rate Policies in Emerging Market Economies. Journal of International Money and Finance 60: 172-96. [CrossRef]

Hafner, Christian, and Alexandre Lauwers. 2015. An Augmented Taylor Rule for the Federal Reserve's Response to Asset Prices. International Journal of Computational Economics and Econometrics 7: 115-51. [CrossRef]

Hofmann, Boris, and Bilyana Bogdanova. 2012. Taylor Rules and Monetary Policy: A Global 'Great Deviation'. IS Quarterly Review. Basel: BIS, pp. 37-49.

Levin, Andrew, Wieland Volker, and John Williams. 1999. Robustness of Simple Monetary Policy Rules under Model Uncertainty. Chicago: University of Chicago Press.

Lubick, Thomas, and Frank Schorfheide. 2007. Do Central banks React to Exchange Rate Movements: A Structural Investigation. Journal of Monetary Economics 54: 1069-87. [CrossRef]

Markov, Nikolay, and Thomas Nitschka. 2013. Estimating Taylor Rules for Switzerland: Evidence from 2000-2012. In Swiss National Bank Working Papers. Zurich: SNB.

Morley, Bruce, and Qijia Wei. 2012. The Taylor Rule and House Price Uncertainty. Applied Economics Letters 19: 1449-53. [CrossRef]

Obstfeld, Maurice, and Ken Rogoff. 1995. The Mirage of Fixed Exchange Rates. NBER Working Paper No. 5191. Cambridge: NBER, pp. 1-35. 
Svensson, Lars. 2003. Using Judgment in Monetary Policy through Targeting Rules. Journal of Economic Literature 41: 426-77. [CrossRef]

Takats, Elod, and Abraham Vela. 2014. International Monetary Policy Transmission. BIS Papers 78: 25-44.

Taylor, John. 1993. Discretion versus Policy Rules in Practice. Carnegie-Rochester Conference Series on Public Policy 39: 195-214. [CrossRef]

Taylor, John. 2000. Using Monetary Policy Rules in Emerging Market Economies. Paper presented at the 75th Anniversary Conference on "Stabilization and Monetary Policy: The International Experience", November 14-15; pp. 1-19.

Taylor, John. 2001. The Role of the Exchange Rate in Monetary-Policy Rules. The American Economic Review 91: 263-67. [CrossRef]

Taylor, John. 2007. Housing and Monetary Policy. NBER Working Paper No. 13682. Cambridge: NBER.

Taylor, John. 2003. International Monetary Policy Coordination: Past, Present and Future. BIS Working Papers No. 437. Basel: BIS.

Taylor, John, and John Williams. 2010. Simple and Robust Rules for Monetary Policy. Handbook of Monetary Economics 3: 829-59.

(C) 2020 by the authors. Licensee MDPI, Basel, Switzerland. This article is an open access article distributed under the terms and conditions of the Creative Commons Attribution (CC BY) license (http://creativecommons.org/licenses/by/4.0/). 